\title{
BUSINESS RISK MANAGEMENT PRACTICES ADOPTED BY ENTREPRENEURS FOR BUSINESS SUCCESS IN DELTA STATE
}

\author{
Ikelegbe, Samuel \\ Office Technology and Management \\ School of Business Studies \\ Delta State Polytechnic, Ogwashi Uku \\ ikelegbesamuel@yahoo.com \\ Udeh, Romanus \\ Office Technology and Management \\ School of Business Studies \\ Delta State Polytechnic, Ogwashi Uku \\ udehromanus72@gmail.com
}

\begin{abstract}
The study was a survey research; it focused on determining the extent entrepreneurs adopt risk management practices for business management practice in Delta State. The population of the study comprises of 860 business owners who are registered with the Ministry of Commerce and Industries in Delta State. The instrument for data collection was a structured questionnaire with 16 items. Data collected were analyzed using mean and Standard deviation. The null hypothesis was tested using ANOVA statistics at 0.05 level of significance. Findings from the investigation revealed that entrepreneurs in Delta State do not adopt business risk management practices in managing their businesses. It was recommended among others that the Delta State Government and Ministry of Commerce and Industries should sensitize business owners on business risk management practice to enhance business success.
\end{abstract}

Keywords: Entrepreneurs, risk, business risk management. 


\section{Introduction}

Entrepreneurs play a large role in any economy as they provide the zeal for growth and development. The term "entrepreneur" is a French word which means one who undertakes tasks in the production process. The roles played by entrepreneurs contribute to the growth and development of economies. Entrepreneurs are individuals who accept risks, mobilize resources, provide labour, introduce innovation and create economic activities. According to Oba in Ameh and Ezeahrukwe (2016), entrepreneurs are risk takers, innovators and creators who initiate actions. In the views of Fredrick and Silas (2017), entrepreneurs formed the backbone of every economy. Eze (2018) describe an entrepreneur as someone who assumes the responsibility and the risk for a business operation with the expectation of making profit. The entrepreneur generally decides on the product, acquires the facilities and brings together the labour force, capital and production materials. If the business succeeds, the entrepreneur reaps the reward of profit if it fails he takes the loss. This means entrepreneurs are coordinators and risk bearers.

Risk is the possibility of damage or any other negative occurrences that is caused by external or internal vulnerabilities which may be avoided through preemptive action. Risk is commonly associated with uncertainty, as the event may not happen. It is an essential part of business, because enterprises cannot function without taking risk as business grows through risk taking (Okoli and Okeke, 2019). Entrepreneurs' risks can come from uncertainties in accidents, natural causes and disasters as well as deliberate attacks from an adversary. Risk directly reduce the productivity of entrepreneurs, decrease profitability, reduces quality of production, reputation, brand value and entrepreneurs business earning chances (Binuomote, 2015). It is therefore imperative to understand what constitute risk and also understand how to manage risk.

Business risk management is a subset of risk management used to evaluate the business involved if any change occurs in the business operations, systems and process (www.whatissixsignma.net). Business risk management identifies priorities from unexpected incidents and keeping them on track. It also enables an integrated response to multiple risks and facilitates a more informed risk based decision making capability. Businesses today are unpredictably volatile and seem to become more complex every day. Entrepreneurs today have recognized risk as an evil that should be minimized or mitigated, whenever possible. However, risk assessment provides a mechanism for identifying which risk represent opportunities and which represent potential pitfalls (Ikelegbe, 2015).

Risk can have negative or positive impact on the business. Risk with a negative impact can prevent value creation or erode existing value. Risks with positive impact may offset negative impacts or represent opportunities (www.whatissixsignma.net). In the opinion of Heldmen (2005), business in risk management need to engage in the process of identifying and documenting risks, analyze and prioritize risks, perform risk audits and review. For small and medium enterprises to succeed according to Okoli and Okeke (2019), they must identify key risk to avoid and reduce threats to an acceptable level while maximizing opportunities. An ideal risk management program assists an enterprise to steer clear of potential risks before they occur.

Shimell (2002) averred that effective risk management process is a critical attribute of a successful business. The better the process the more certainty there is of prosperity and 
potential long term competitive advantage. Experience of entrepreneur according to Young in Shimmell (2002) has been identified as one of the factors to be associated with adoption of suitable risk management practices and business failures, many entrepreneurs may lack the needed experience and such could lead to poor business performance.

Regoff (2004) stated that risk management is a practice of systematically selecting cost effective approaches for minimizing the effect of threat realization to the organization. All risks according to him can never be fully avoided or mitigated simply because of financial and political limitations of the entrepreneur. In essence, risk management describes a structured approach in controlling uncertainties and potential dangers by assessing what particular uncertainties and potential dangers are, then developing strategies to minimize or mitigate those uncertainties or dangers. Regoff (2004) however noted that, entrepreneurs require strategies such as risk avoidance, hazard prevention, risk retention, creating risk management plan, provision of fire proof save, keeping accurate stock inventory and control and clearing stock in managing entrepreneurs business risk. An entrepreneur requires training in risk management for effective, efficient and business operation.

\section{Statement of the Problem}

Entrepreneurs' success and development is as a result of survival of their businesses. Many entrepreneurs' ventures into business and within few years are out of business because of uncertainties and risks involve in business and inability of business owners to identify risk associated with the type of business they are into. Many businesses also survive due to luck in the business environment or due to possible chances available for the business success. For every business to grow and to be successful, risk identification is important in order for the business owner not to be out of business. The study is therefore aimed at determining the extent to which entrepreneurs in Delta State adopt risk management practices to avoid loss of their investment.

\section{Purpose of the study}

The main purpose of the study was to determine the extent entrepreneurs adopt risk management practices for business success. Specifically the study sought to:

1. Determine the extent entrepreneurs adopt business risk identification management practices for business success in Delta State.

\section{Research Question}

The following research question guided the study:

1. To what extent do entrepreneurs adopt business risk management practice for business success in Delta State?

\section{Null Hypothesis}

The following null hypothesis was tested at 0.05 level of significance.

1. There is no significant difference in the mean rating of entrepreneurs on the extent business risk management practice is adopted for business success in Delta State based on years of experience (1-5 years, 5 - 10years and above 10 years) 


\section{Method}

The study adopted descriptive survey design. The area of the study was Delta State. A total of 860 business owners (entrepreneurs) who are registered with the Ministry of Commerce and Industries constituted the population. A sample of 750 entrepreneurs was selected using stratified random sampling. A structural questionnaire tilted "Questionnaire on Business Risk Management Practice adopted for success" (QBRMPAS) was used for data collection with the help of two research assistants. The questionnaire items were structured on 5 point rating scale, with response categories and weighted as: Very High Extent (VHE) 4.50 - 5.00, High Extent (H.E) 3.50 - 4.49, Moderate Extent (ME) 2.50 - 3.49, Low Extent (L.E) 1.50 - 2.49, and Very Low Extent (VLE) $0.50-1.49$.

To establish reliability of the instrument, the validated instrument was administered on 20 entrepreneurs in Edo State who were not part of the studied population. Cronbach Alpha was used to analyze the coefficient of the instrument which yielded 0.88 . Out of the 750 copies of questionnaire administered on respondents, 616 were returned and used for the study. Mean and standard deviation were used to analyze the data. The null hypothesis was tested using ANOVA at 0.05 level of significance. The decision rule used for the study was that a null hypothesis was rejected where calculated f-value is equal or greater than the critical value. Where the calculated f-value is less than the critical value, the hypothesis is accepted.

\section{RESULT}

Research question 1: To what extent do entrepreneurs adopt business risk management practice for business success in Delta State?

Table 1: Respondents mean ratings on the extent of adoption of business risk management practice for business success in Delta State.

\begin{tabular}{lccc}
\hline S/N Items & Mean & SD & Decision \\
\hline 1. Develop risk registers & & & \\
2. Analyze and prioritize risk & 2.05 & 0.71 & Low extent \\
3. Perform risk auditing & 2.18 & 0.74 & Low extent \\
4. Review risk to understand current situation & 1.75 & 0.68 & Low extent \\
5. Put measure to insure business against risk & 1.83 & 0.96 & Low extent \\
6. hazard prevention strategies are put in place & 3.65 & 0.69 & Low extent \\
7. Creating risk management plan & 1.88 & 1.22 & High extent \\
8. Provision of fire proof & 3.75 & 0.87 & Low extent \\
9. Keeping accurate stock & 3.68 & 1.03 & High extent \\
10.Clearing stock periodically & 1.96 & 0.93 & High extent \\
11. Identification of criteria for risk evaluation & 2.36 & 1.02 & Low extent \\
12. Identifying risk events & 1.96 & 0.93 & Low extent \\
13. Identifying risk treatment option & 2.36 & 1.02 & Low extent \\
14. Selecting risk treatment options & 1.97 & 0.93 & Low extent \\
15. implementing risk treatment option & 1.88 & 0.94 & Low extent \\
16. regular reviewing of identified risk & 1.86 & 0.94 & Low extent \\
$\quad$ Cluster Mean & $\mathbf{2 . 2 7}$ & $\mathbf{0 . 9 1}$ & Low extent \\
\hline
\end{tabular}


The data contained in Table 1 indicates that items 6, 8, and 9 were rated high extent. All other items were rated low extent. However with a cluster mean of 2.27 which is within the boundary limit of low extent, it is concluded that entrepreneurs' rated business risk management practice as low extent in Delta State. The closeness of the standard deviation scores which ranges from $0.68-1.22$ indicates homogeneity in the respondents' opinion.

\section{Null Hypothesis}

There is no significant difference in the mean rating of entrepreneurs on the extent business risk management practices are adopted for business success in Delta State based on years of experience (1-5 years, 5-10 years and above 10 years).

Table 2: ANOVA analyses of the respondents mean rating on the extent business risk management are adopted based on years of experience.

\begin{tabular}{lrllllll}
\hline $\begin{array}{l}\text { Sources of } \\
\text { Variance }\end{array} \begin{array}{c}\text { Sum of } \\
\text { square }\end{array}$ & Mean & DF & F/ratio & F/prob. Alpha level & Remarks \\
\hline Between Groups & 52.29 & 26.14 & 2 & & & & \\
& & & & 26.60 & 0.00 & 0.05 & Accepted \\
Within Groups 549.81 & 1.06 & 514 & & & & \\
\hline
\end{tabular}

Table 2 shows f-calculated values with f-test value of 0.00 which is less than the accepted alpha level of 0.05. There is therefore enough evidence to accept the null hypothesis. This indicates that entrepreneurs do not differ in their mean ratings on the extent business risk management practices are adopted for business success based on experience.

\section{Discussion of findings}

The findings of the study indicate that entrepreneurs adopted risk management to a low extent in Delta State. However, hazard prevention strategies, provision of fire proof, and keeping accurate stock were rated high extent. With a mean of 2.27, it is concluded that entrepreneurs' risk management practice in Delta State is rated low extent. These findings are in line with Okoli and Okeke (2019) that carried out a similar study in Anambra state. The findings revealed that small and medium scale entrepreneurs adopted risk management practices to a low extent. Also, Udemba (2019) conducted a study titled, risk identification strategies practices utilized by operators of small and medium scale enterprises in management of business resources in Anambra State. The study equally revealed that operators of SMEs utilized risk identification practices to a low extent. Both studies and the present study are similar but different in the area of their study. While the present study is carried out in Delta State, the former studies were conducted in Anambra State. Furthermore, the hypothesis tested using ANOVA statistics revealed that entrepreneurs differ in their mean responses on the extent business risk management practices are adopted based on experienced. This might be so because of the low extent of awareness and mode of operation of the different business owners and perhaps financial differences as well. 


\section{Conclusion}

In view of the findings of this study, it was concluded that entrepreneurs in Delta State do not adopt business risk management practices. This is a major setback to business growth in Delta State.

\section{Recommendations}

Based on the findings of the study, it is recommended that:

1. The Delta State government and the Ministry of Commerce and Industries should sensitize business owners through workshops, seminars and conferences on business risk management practice to enhance business success.

2. Small and Medium Enterprises Development Agency of Nigeria (SMEDAN) should collaborate with business owners and entrepreneurs to ensure business owners adopt measures to aid in adopting business risk management to stimulate growth and development of enterprises.

3. Entrepreneurs and their staff should endeavour to attend business training on the skill to effectively manage risk for business success. 


\section{References}

Ameh, A.O. \& Ezeahurukwe, N.L. (2016). Entrepreneurs' Perception of competencies required by Polytechnic graduates for business and economic survival in a dwindling Nigeria n economy. Conference Proceedings of Association of Business Educator of Nigeria. 3(1), 260-271.

Binuomote, M.O. (2015). Training needs of business education students for entrepreneurial development in South-West geo political zone of Nigeria, A project Thesis submitted to the Department of Business education Education, Ebonyi State University, Abakaliki.

Business risk management: www.whattissixsigma.

Eze, F.O. (2008). Practical guide to entrepreneurship: A modern approach. Oshogbo. Mckay venture.

Fredrick, K. L. \& Silas, T. N. (2017). Assessing entrepreneurs characteristics among small business in Jos South Local Government area of Plateau State. Nigeria Journal of Business Educators of Nigeria. \$(2), 85-94.

Heldman, K. (2005). Project manager's spotlight on risk management. Alameda: Harbor Light press.

Ikelegbe, S. (2015). Managing business risk in the face of a dwindling economy. A Seminar paper presented to the department of Business Education, Ebonyi State University Abakaliki.

Regoff, E. (2004). "Who done it"? Attribution by entrepreneurs and experts of the factors that cause and impede small business success. Journal of small Business Management, 42(4), 364-376.

Okoli, C.I. \& Okeke, S.I. (2019). Assessment of suitable risk management practices adopted by owners of SME in Anambra State for institutional collaborations for business success in the e-world. Journal of Association of business Education of Nigeria 6(1), 64-70.

Shemill, P. (20020. The Universe of risk: How top business leaders control risk and achieve success. London: Pearson education Limited.

Udemba, F.N. (2019). Risk identification practices utililized by operators of small and medium scale enterprises in the management of business resources in Anambra State. Conference Proceedings of Association of Business Educators of Nigeria. 6(1), 81-89. 